\title{
Assessing the adequacy of pressure ulcer prevention in hospitals: a nationwide prevalence survey
}

Katrien Vanderwee, ${ }^{1}$ Tom Defloor, ${ }^{1}$ Dimitri Beeckman, ${ }^{1,2}$ Liesbet Demarré, ${ }^{1}$ Sofie Verhaeghe, ${ }^{1}$ Thérèse Van Durme, ${ }^{3}$ Micheline Gobert ${ }^{3}$
${ }^{1}$ Nursing Science, Department of Public Health, Faculty of Medicine and Health Sciences, Ghent University, Gent, Belgium ${ }^{2}$ Department of Bachelor in Nursing, University College Arteveldehogeschool Ghent, Gent, Belgium

${ }^{3}$ Interdisciplinary Research Unit in Nursing Clinics and Sciences, Research Institute in Health and Society, Department of Public Health, Faculty of Medicine, Catholic University of Louvain, Brussels, Belgium

\section{Correspondence to} Katrien Vanderwee, Nursing Science, Department of Public Health, Faculty of Medicine and Health Sciences, Ghent University, UZ Blok A-2nd floor, De Pintelaan 185, Gent 9000 , Belgium; katrien. vanderwee@ugent.be

Accepted 3 July 2010
Introduction: The development of a pressure ulcer is an adverse event and is often avoidable if adequate preventive measures are applied. No large-scale data, based on direct patient observations, are available regarding the pressure ulcer preventive interventions used in hospitals.

Purpose: The aim of this study was to obtain insight into the adequacy of interventions used to prevent pressure ulcers in Belgian hospitals.

Methods: A cross-sectional, multi-centre pressure ulcer prevalence study was performed in Belgian hospitals.

The methodology used to measure pressure ulcer prevalence was developed by the European Pressure Ulcer Advisory Panel. The data collection instrument includes five categories of data: general data, patient data, risk assessment, skin observation and prevention.

Results: The total sample consisted of 19968 patients. The overall prevalence of pressure ulcers Category I-IV was $12.1 \%$. Only $10.8 \%$ of the patients at risk received fully adequate prevention in bed and while sitting. More than $70 \%$ of the patients not at risk received some pressure ulcer prevention while lying or sitting.

Concusion: Generally, there is a limited use of adequate preventive interventions for pressure ulcers in hospitals, which reflects a rather low quality of preventive care. The implementation of pressure ulcer guidelines requires more attention. The pressure ulcer prevention used in practice should be re-evaluated on a regular basis.

\section{INTRODUCTION}

Pressure ulcers (PUs) are a serious complication of hospitalisation in terms of increased morbidity, mortality, healthcare expenditure, extended hospital stay and patient suffering. ${ }^{1-6}$ PU prevalence in hospitals has been reported to range from $7 \%$ to $26 \% .^{7-13} \mathrm{PU}$ prevalence data are commonly used as an indicator for the quality of (nursing) care. ${ }^{1415}$ The development of a PU is an adverse event and is (often) avoidable with adequate prevention. Adequate PU prevention involves assigning effective preventive measures, consisting of a reduction of the intensity and/ or the duration of pressure and shearing forces on the tissue, to patients at risk for PU development. $^{1617}$

Since 2001, the Belgian evidence-based PU prevention guideline is available and easily accessible. So far, no large-scale data, based on direct patient observations, are available on PU preventive interventions carried out in Belgian hospitals. Therefore, this study aimed to obtain insight into the adequacy of preventive interventions for PUs in Belgian hospitals and evaluating PU prevalence.

\section{METHODS}

\section{Setting and sample}

This cross-sectional, multi-centre prevalence study was carried out in Belgian hospitals. All hospitals $(n=143)$, except psychiatric hospitals, were invited to participate. Eighty-four hospitals $(68 \%)$ agreed to participate. All wards were surveyed, with the exception of day care, psychiatry, paediatric and maternity wards. PUs are seldom observed in patients admitted to these wards. ${ }^{18}$

Patients $>18$ years were included. Each patient or relative was asked to consent to participate in the survey. This study was approved by the ethics review committee of Ghent University Hospital (No B7020072953) and of each participating hospital.

\section{Data collection}

The methodology used to measure PU prevalence was developed by the European Pressure Ulcer Advisory Panel (EPUAP). ${ }^{9}$ This 
methodology has been tested in different European countries and is evaluated as sufficiently robust to measure and compare PU prevalence and prevention in different hospitals. ${ }^{9}$ The EPUAP method consists of a minimum dataset and a uniform procedure.

\section{Data collection instrument}

The data collection instrument included five categories of data: general data, patient data, risk assessment, skin observation and prevention. General data contained type of hospital and ward. Patient data included age, gender and incontinence. The Braden Scale was used to assess the PU risk of each patient. ${ }^{19}$ This scale has been most widely examined for its predictive validity. ${ }^{20}{ }^{21}$ In Belgium, patients with a Braden score $<17$ are generally considered as being in need of preventive measures. ${ }^{16}$ Skin observation consisted of details on PUs (category and location). PUs were categorised according to the NPUAP-EPUAP classification system ${ }^{17}$ : Category I is nonblanchable erythema of intact skin, Category II is partial thickness skin loss or blister, Category III is full thickness skin loss and Category IV is full thickness tissue loss. Finally, data on PU preventive measures included prevention in bed and while sitting. Data on materials used and repositioning frequency were recorded. The use of materials was observed by the nurses. They recorded whether the material was present in patient's bed or armchair and whether the patient was in bed or in the armchair at the time of the observation. The repositioning frequency was based on the reported frequency in the patient chart. Both evidence-based effective and non-effective measures were registered. The data collection instrument was developed using the software package SNAP Surveys V.SNAP 9 Professional (Snap Surveys, Inc).

\section{Procedure}

In each participating hospital a supervisor was appointed who was responsible for the local organisation of the study. Prior to the study, all supervisors attended a training session. This consisted of: (1) a theoretical training (pathophysiology, classification, risk assessment using the Braden Scale and prevention); (2) an introduction to the study aims and protocol and (3) the use of the data collection instrument. The purpose of this training was to ensure the correctness and uniformity of completing the data collection instrument.

The supervisor composed teams of nurses who collected the data on the wards. Each team consisted of two nurses: a nurse from the staff of the ward being surveyed and a nurse working in another ward. The first nurse could provide relevant background information about individual patients. Accordingly, all patients were observed by two nurses. Both nurses had to agree about the PU classification. If they disagreed, the opinion of the non-ward nurse was decisive.

The supervisors instructed the teams about the study procedure. Therefore, supervisors received a PowerPoint presentation and an information guide on the study procedure to increase the reliability of the data collection. ${ }^{22} 23$

For practical reasons, participating wards were allowed to choose one day between 15 and 25 April 2008 to perform the study.

\section{Data analysis}

The adequacy of PU preventive interventions was assessed for patients at risk (Braden score $<17$ or having a PU) according to a predefined algorithm (figure 1). This algorithm was constructed based on the Belgian evidence-based PU prevention guideline. ${ }^{16}$ The algorithm took into account the prevention while lying in bed, including type of mattress, repositioning scheme and offloading the heels from the mattress, and while sitting in an armchair, including type of cushion and repositioning scheme. ${ }^{16}$ An assessment of whether patients not at risk for PU development received no PU prevention was also carried out.

All statistical analyses were performed with the software package SPSS V.15.0 (SPSS, Inc). Descriptive data are presented in frequencies and percentages. The overall prevalence of PUs was based on the number of patients with a PU. If a patient had different PUs, the PU with the severest category was taken into account.
Figure 1 Algorithm of adequate preventive measures for patients at risk.

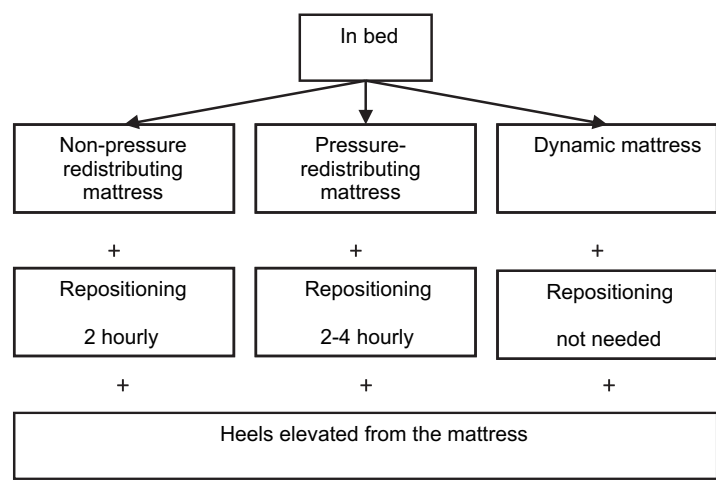

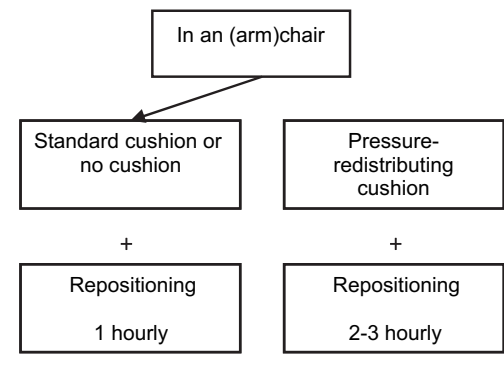




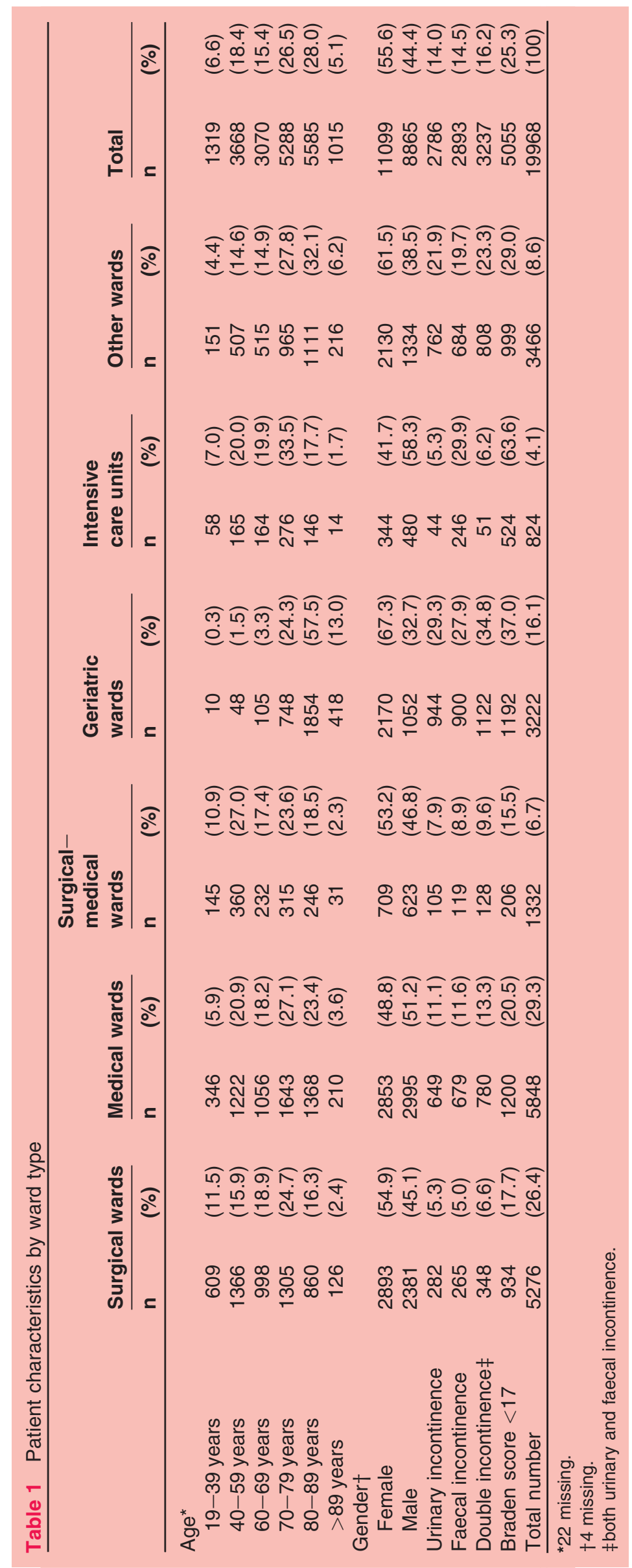


Table 2 Prevalence of pressure ulcers Category I-IV and Category II-IV by ward type (N=19968)

\begin{tabular}{|c|c|c|c|c|}
\hline & \multicolumn{2}{|c|}{ Pressure ulcers Category I-IV } & \multicolumn{2}{|c|}{ Pressure ulcers Category II-IV } \\
\hline & $\mathbf{n}$ & $(\%)$ & $\mathbf{n}$ & (\%) \\
\hline Surgical wards & 426 & (8.1) & 226 & (4.3) \\
\hline Medical wards & 648 & $(11.1)$ & 361 & (6.2) \\
\hline Surgical-medical wards & 85 & $(6.4)$ & 42 & (3.2) \\
\hline Geriatric wards & 609 & (18.9) & 395 & (12.3) \\
\hline Intensive care units & 164 & (19.9) & 107 & (13.0) \\
\hline Other wards & 487 & (14.1) & 265 & $(7.8)$ \\
\hline Total & 2419 & (12.1) & 1396 & (7.0) \\
\hline
\end{tabular}

\section{RESULTS}

In total, 1005 out of 2043 potential hospital wards participated. The total sample consisted of 19968 patients. The majority of the patients $(62.4 \%)$ were admitted to surgical and medical wards (table 1). Almost $60 \%$ of the patients were aged $\geq 70$ years and about $25 \%$ were at risk for PUs according to the Braden Scale.

The overall prevalence of PUs Category I-IV was $12.1 \%$ and Category II-IV was $7 \%$. Intensive care units and geriatric wards had the highest prevalence figures (table 2). Table 3 provides details on the location and categories of PUs. Sacrum and heels were most frequently affected locations. This analysis was based on the total number of PUs observed.

Findings on the adequacy of the applied prevention by ward type are provided in table 4. In intensive care units, the highest percentage of patients at risk (30.4\%) received adequate preventive measures in bed and while sitting in an armchair, whereas on wards with surgical patients the lowest figures $(6.2 \%, 6.6 \%)$ were reported. Overall, only $10.8 \%$ of the patients at risk received fully adequate prevention. The majority of patients at risk $(73.5 \%)$ received partly adequate prevention, which was defined as not all required preventive measures were applied in bed and/or armchair. Generally, a higher percentage of patients at risk received adequate prevention in an armchair (34\%) than in bed (25.5\%). More than $70 \%$ of the patients not at risk received (some) prevention while lying or sitting (table 4).

Details on inadequate preventive measures in at risk patients are presented in table 5. Heels were not offloaded in $60.8 \%$ of the patients at risk. While sitting, the most occurring failure was patients having a standard

Table 3 Location and categories of the pressure ulcers ${ }^{*}$ by ward type $(\mathrm{N}=19968)$

\begin{tabular}{|c|c|c|c|c|c|c|c|}
\hline Location & $\begin{array}{l}\text { Surgical } \\
\text { wards } \\
\text { n (\%) }\end{array}$ & $\begin{array}{l}\text { Medical } \\
\text { wards } \\
\text { n (\%) }\end{array}$ & $\begin{array}{l}\text { Surgical-medical } \\
\text { wards } \\
\text { n (\%) }\end{array}$ & $\begin{array}{l}\text { Geriatric } \\
\text { wards } \\
\text { n (\%) }\end{array}$ & $\begin{array}{l}\text { Intensive } \\
\text { care units } \\
\text { n (\%) }\end{array}$ & $\begin{array}{l}\text { Other } \\
\text { wards } \\
\text { n (\%) }\end{array}$ & $\begin{array}{l}\text { Total } \\
\text { n (\%) }\end{array}$ \\
\hline Sacrum & 285 (52.2) & 435 (51.6) & $61(55.5)$ & $359(45.4)$ & $93(40.2)$ & $256(44.5)$ & $1489(48.1)$ \\
\hline Category I & 149 (27.3) & $227(27.1)$ & 31 (28.2) & 144 (18.2) & 37 (16.0) & $147(25.5)$ & $735(23.8)$ \\
\hline Category II & 66 (12.1) & 115 (13.7) & $16(14.5)$ & 91 (11.5) & $36(15.6)$ & 66 (11.5) & $390(12.6)$ \\
\hline Category III & $41(7.5)$ & $63(7.5)$ & $7(6.4)$ & $76(9.6)$ & $16(6.9)$ & $39(6.8)$ & $242(7.8)$ \\
\hline Category IV & $29(5.3)$ & $30(3.6)$ & $7(6.4)$ & $48(6.1)$ & $4(1.7)$ & $4(0.7)$ & 122 (3.9) \\
\hline Heels & 199 (36.5) & 277 (33.1) & $38(34.6)$ & 341 (43.2) & 80 (34.7) & 249 (43.2) & $1184(38.4)$ \\
\hline Category I & $96(17.6)$ & $114(13.6)$ & $23(20.9)$ & 125 (15.8) & $31(13.4)$ & 113 (19.6) & 502 (16.2) \\
\hline Category II & $33(6.1)$ & 61 (7.3) & $8(7.3)$ & 70 (8.9) & $22(9.6)$ & $40(6.9)$ & $234(7.6)$ \\
\hline Category III & $35(6.4)$ & $47(5.6)$ & $6(5.5)$ & 73 (9.2) & $16(6.9)$ & 47 (8.2) & 224 (7.3) \\
\hline Category IV & $35(6.4)$ & $55(6.6)$ & $1(0.9)$ & 73 (9.3) & $11(4.8)$ & 49 (8.5) & 224 (7.3) \\
\hline Hips & $8(1.6)$ & $23(2.8)$ & $3(2.7)$ & 25 (3.2) & $10(4.3)$ & $13(2.2)$ & $82(2.6)$ \\
\hline Category I & $1(0.2)$ & 14 (1.7) & $2(1.8)$ & 10 (1.3) & $4(1.7)$ & 7 (1.2) & 38 (1.2) \\
\hline Category II & $1(0.2)$ & $2(0.3)$ & $0(0.0)$ & $6(0.8)$ & $3(1.3)$ & $3(0.5)$ & $15(0.5)$ \\
\hline Category III & $3(0.6)$ & $6(0.7)$ & $1(0.9)$ & $4(0.5)$ & $1(0.4)$ & $0(0.0)$ & $15(0.5)$ \\
\hline Category IV & $3(0.6)$ & $1(0.1)$ & $0(0.0)$ & $5(0.6)$ & $2(0.9)$ & $3(0.5)$ & $14(0.4)$ \\
\hline Other & $53(9.7)$ & 103 (12.2) & $8(7.2)$ & 66 (8.2) & $48(20.8)$ & $58(10.1)$ & $336(10.9)$ \\
\hline Category I & 27 (4.9) & $47(5.6)$ & $5(4.5)$ & 27 (3.4) & $14(6.1)$ & $20(3.5)$ & $140(4.5)$ \\
\hline Category II & $10(1.8)$ & 27 (3.2) & $1(0.9)$ & $17(2.1)$ & 19 (8.2) & $16(2.8)$ & $90(2.9)$ \\
\hline Category III & $13(2.4)$ & 17 (2.0) & $2(1.8)$ & 13 (1.6) & 7 (3.0) & $15(2.6)$ & 67 (2.2) \\
\hline Category IV & $3(0.6)$ & $12(1.4)$ & $0(0.0)$ & $9(1.1)$ & $8(3.5)$ & 7 (1.2) & 39 (1.3) \\
\hline Total & 545 & 383 & 110 & 791 & 231 & 576 & 3091 \\
\hline
\end{tabular}

*Based on the total number of pressure ulcers observed. 
Table 4 Adequate pressure ulcer (PU) prevention in patients at risk (Braden score $<17$ or PU) and not at risk by ward type

\begin{tabular}{|c|c|c|c|c|c|c|c|}
\hline & $\begin{array}{l}\text { Surgical } \\
\text { wards } \\
\text { n (\%) }\end{array}$ & $\begin{array}{l}\text { Medical } \\
\text { wards } \\
\text { n (\%) }\end{array}$ & $\begin{array}{l}\text { Surgical- } \\
\text { medical } \\
\text { wards } \\
\mathrm{n}(\%)\end{array}$ & $\begin{array}{l}\text { Geriatric } \\
\text { wards } \\
\text { n (\%) }\end{array}$ & $\begin{array}{l}\text { Intensive } \\
\text { care units } \\
\text { n (\%) }\end{array}$ & $\begin{array}{l}\text { Other } \\
\text { wards } \\
\text { n (\%) }\end{array}$ & $\begin{array}{l}\text { Total } \\
\text { n (\%) }\end{array}$ \\
\hline $\begin{array}{l}\text { Patients at risk } \\
\text { In bed and armchair }\end{array}$ & 1123 & 1429 & 241 & 1372 & 543 & 1205 & 5913 \\
\hline $\begin{array}{l}\text { Fully adequate } \\
\text { prevention* }\end{array}$ & $74(6.6)$ & $121(8.5)$ & $15(6.2)$ & 165 (12.0) & $165(30.4)$ & $96(8.0)$ & $636(10.8)$ \\
\hline $\begin{array}{l}\text { Partly adequate } \\
\text { prevention } \dagger\end{array}$ & 852 (75.9) & 1034 (75.9) & 178 (73.9) & 1001 (73.0) & 323 (59.5) & 960 (79.7) & $4348(73.5)$ \\
\hline $\begin{array}{l}\text { No adequate } \\
\text { prevention } \neq\end{array}$ & 197 (17.5) & 274 (19.2) & 48 (19.9) & 206 (15.0) & $55(10.1)$ & $149(12.4)$ & 929 (15.7) \\
\hline \multicolumn{8}{|l|}{ In bed } \\
\hline $\begin{array}{l}\text { Fully adequate } \\
\text { prevention }\end{array}$ & 196 (17.5) & 298 (20.9) & 33 (13.7) & $501(36.5)$ & 196 (36.1) & $283(23.5)$ & $1507(25.5)$ \\
\hline $\begin{array}{l}\text { Partly adequate } \\
\text { prevention }\end{array}$ & 789 (70.3) & 974 (68.2) & $169(70.1)$ & $811(59.1)$ & $312(57.5)$ & $832(69.0)$ & $3887(65.7)$ \\
\hline $\begin{array}{l}\text { No adequate } \\
\text { prevention }\end{array}$ & 138 (12.3) & 157 (11.0) & 39 (16.2) & $60(4.4)$ & $35(6.4)$ & $90(7.5)$ & $519(8.8)$ \\
\hline \multicolumn{8}{|l|}{ In armchair } \\
\hline $\begin{array}{l}\text { Fully adequate } \\
\text { prevention }\end{array}$ & 426 (37.9) & 442 (30.9) & $86(35.7)$ & 327 (28.3) & $440(81.0)$ & $290(24.1)$ & 2011 (34.0) \\
\hline $\begin{array}{l}\text { Partly adequate } \\
\text { prevention }\end{array}$ & $171(15.2)$ & 214 (15.0) & 27 (11.2) & 430 (31.3) & $23(4.2)$ & $385(32.0)$ & $1250(21.1)$ \\
\hline $\begin{array}{l}\text { No adequate } \\
\text { prevention }\end{array}$ & $526(46.8)$ & 773 (54.1) & $128(53.1)$ & $615(44.8)$ & $80(14.7)$ & $530(44.0)$ & 2652 (44.9) \\
\hline $\begin{array}{l}\text { Patients not at risk } \\
\text { In bed and armchair }\end{array}$ & 4153 & 4419 & 1091 & 1850 & 281 & 2261 & 14055 \\
\hline Correct: no prevention & 1269 (30.6) & $1391(31.5)$ & $370(33.9)$ & $427(23.1)$ & $47(16.7)$ & $580(25.7)$ & $4084(29.1)$ \\
\hline $\begin{array}{l}\text { Incorrect: prevention } \\
\text { In bed }\end{array}$ & $2884(69.4)$ & $3028(68.5)$ & $721(66.1)$ & 1423 (76.9) & 234 (83.3) & $1681(74.3)$ & 9971 (70.9) \\
\hline Correct: no prevention & $1333(32.1)$ & $1441(32.6)$ & $377(34.6)$ & $501(27.1)$ & 56 (19.9) & $641(28.4)$ & 4349 (30.9) \\
\hline $\begin{array}{l}\text { Incorrect: prevention } \\
\text { In armchair }\end{array}$ & $2820(67.9)$ & $2978(67.4)$ & $714(65.4)$ & 1349 (72.9) & $225(80.1)$ & $1620(71.6)$ & $9709(69.1)$ \\
\hline Correct: no prevention & 3908 (94.1) & $4221(95.5)$ & $1072(98.3)$ & $1461(79.0)$ & $238(84.7)$ & $1913(84.6)$ & $12813(91.2)$ \\
\hline Incorrect: prevention & $245(5.9)$ & $198(4.5)$ & $19(1.7)$ & $389(21.0)$ & $43(15.3)$ & $348(15.4)$ & $1242(8.8)$ \\
\hline
\end{tabular}

*Effective preventive measures.

†some preventive measures.

$\ddagger$ no preventive measures.

cushion or no cushion in combination with an inadequate repositioning frequency $(72.3 \%)$.

\section{DISCUSSION}

This study revealed a PU prevalence of $12.1 \%$ in Belgian hospitals, which is in line with other international studies. $^{7-13}$ The PU prevalence was the highest on geriatric and intensive care wards and the heels and sacrum were the most affected sites. Both these findings are also consistent with other international studies. ${ }^{7-13}$ Geriatric and intensive care patients are high risk patients to develop PUs. They have multiple risk factors, such as limited mobility and activity, higher age, perfusion and oxygenation problems, and a reduced general health status, which explains their high level of risk. ${ }^{24-30}$ The proportion of sacral and heel PUs was rather high.
Specifically, heel PUs are often viewed as a (outcome) quality indicator, as most heel ulcers can easily be prevented. $^{16}$

The main purpose of this study was to gain insight into the adequacy of preventive interventions for PUs in Belgian hospitals. This gives us more information about the process of nursing care and can be used as a quality indicator. The results of this study indicate that the adequacy of PU prevention in Belgian hospitals was suboptimal. Only 1 out of 10 patients at risk for PUs received fully adequate prevention. A significant number of patients not at risk received some kind of preventive measure which is, in fact, unnecessary and inefficient. ${ }^{2} 31$

Prevention while sitting and heel prevention can be described as problematic. Prevention while sitting is of utmost importance as the pressure on the sacrum is higher in the sitting position compared to the lying 
Table 5 Inadequate pressure ulcer (PU) preventive measures in at risk patients (Braden score $<17$ or PU) by ward type $(\mathrm{N}=5913)$

\begin{tabular}{|c|c|c|c|c|c|c|c|}
\hline & $\begin{array}{l}\text { Surgical } \\
\text { wards } \\
\text { n (\%) }\end{array}$ & $\begin{array}{l}\text { Medical } \\
\text { wards } \\
\text { n (\%) }\end{array}$ & $\begin{array}{l}\text { Surgical- } \\
\text { medical } \\
\text { wards } \\
\text { n (\%) }\end{array}$ & $\begin{array}{l}\text { Geriatric } \\
\text { wards } \\
\text { n (\%) } \\
\end{array}$ & $\begin{array}{l}\text { Intensive } \\
\text { care units } \\
\text { n (\%) }\end{array}$ & $\begin{array}{l}\text { Other } \\
\text { wards } \\
\text { n (\%) }\end{array}$ & $\begin{array}{l}\text { Total } \\
\mathrm{n}(\%) \\
\end{array}$ \\
\hline $\begin{array}{l}\text { Patients at risk } \\
\text { In bed }\end{array}$ & 1123 & 1429 & 241 & 1372 & 543 & 1205 & 5913 \\
\hline \multicolumn{8}{|l|}{ Mattress } \\
\hline $\begin{array}{l}\text { Standard mattress with no } \\
\text { adequate repositioning frequency }\end{array}$ & $202(18.0)$ & $237(16.6)$ & $58(24.1)$ & $131(9.5)$ & $16(0.3)$ & $136(11.3)$ & $780(13.2)$ \\
\hline $\begin{array}{l}\text { Pressure-redistributing mattress } \\
\text { with no adequate repositioning } \\
\text { frequency }\end{array}$ & $533(47.5)$ & $497(34.8)$ & $91(37.7)$ & $310(22.6)$ & $77(1.4)$ & 389 (32.3) & $1897(32.1)$ \\
\hline Total & $735(65.5)$ & $734(27.5)$ & $149(61.8)$ & $441(32.1)$ & $93(1.7)$ & $525(43.6)$ & $2677(45.3)$ \\
\hline \multicolumn{8}{|l|}{ Heel prevention } \\
\hline $\begin{array}{l}\text { Heels not elevated from the } \\
\text { mattress }\end{array}$ & $674(18.7)$ & $967(26.9)$ & $168(4.7)$ & $716(19.9)$ & $323(9.0)$ & $748(20.8)$ & $3596(60.7)$ \\
\hline \multicolumn{8}{|l|}{ Mattress $^{(1)}+$ heel prevention } \\
\hline $\begin{array}{l}\text { Inadequate prevention on } \\
\text { mattress and heels not elevated } \\
\text { from mattress }\end{array}$ & $927(21.0)$ & $1131(25.7)$ & $208(4.7)$ & $871(19.8)$ & $347(7.9)$ & $922(20.9)$ & $4406(74.5)$ \\
\hline In armchair & & & & & & & \\
\hline \multicolumn{8}{|l|}{ Cushion } \\
\hline $\begin{array}{l}\text { Standard cushion or no cushion } \\
\text { with no adequate repositioning } \\
\text { frequency }\end{array}$ & $532(47.4)$ & $800(56.0)$ & $131(5.4)$ & $700(51.0)$ & $81(1.5)$ & $577(47.9)$ & $2821(47.7)$ \\
\hline $\begin{array}{l}\text { Pressure-redistributing cushion } \\
\text { with no correct repositioning } \\
\text { frequency }\end{array}$ & $165(14.7)$ & $187(13.1)$ & $24(0.6)$ & $345(25.1)$ & $22(0.4)$ & $338(28.0)$ & 1081 (18.3) \\
\hline Total & $697(62.1)$ & $987(69.1)$ & $155(4.0)$ & 1045 (76.1) & 103 (1.9) & $915(75.0)$ & 3901 (66.0) \\
\hline
\end{tabular}

position. Adequate prevention of heel PUs requires a complete relief of pressure/shear at the heel zone. This is necessary because of the combination of a microcirculatory system, which is very susceptible to pressure and shearing alterations, and the normal physiological changes of the skin in aged patients. Moreover, the heel surface is too small to spread pressure through devices. ${ }^{32}$ In fact, the principle of elevating the heels from the mattress by a device such as a (wedgeshaped) cushion, a heel pad or a heel boot is recommended and should be easily attainable. ${ }^{17}$

Other international studies reported similar worrisome findings concerning the use of adequate PU prevention in hospitals. In a Swedish study, the majority of patients at risk for or with PUs did not get appropriate prevention while in bed or sitting in a chair. ${ }^{33}$ Bours et al found that only half of the patients who needed a pressure-redistributing mattress were positioned on such a support surface and that less than $33 \%$ of the patients needing to be repositioned were actually being turned. ${ }^{18}$ Lyder et al evaluated national estimates of compliance with the process of care for patients at risk for PU. They found that a pressure-reducing device was used for only $7.5 \%$ of those patients and that $66.2 \%$ were reposi- tioned. ${ }^{34}$ Baumgarten et al (2010) studied the use of pressure-redistributing support surfaces among elderly hip fracture patients. ${ }^{35}$ They found that this surface was present in only $36.4 \%$ of their observations. A European pilot survey revealed that only $9.7 \%$ of the patients in need of prevention received adequate preventive care. ${ }^{9}$ A Belgian study, investigating the use of hospital administrative data to evaluate the knowledge-to-action gap in PU preventive care, found that Belgian hospitals frequently failed to provide appropriate prevention. ${ }^{36}$ In that study, $17.5 \%$ of the patients who should have been placed on a dynamic mattress were not. However, in that study no detailed information is given on the preventive strategies as a rather rough algorithm was constructed to evaluate PU prevention. ${ }^{36}$

Generally, there is a limited use of effective preventive interventions for PUs in hospitals, which reflects a rather low quality of PU preventive care resulting in adverse outcomes for patients. This finding is striking because several initiatives have been taken to address the gap between research evidence and clinical practice, which is one of the most persistent problems in the provision of quality healthcare. $^{37}$ Evidence-based guidelines ${ }^{16}$ and e-learning packages on PU classification and prevention 
are freely and easily accessible, and educational meetings have also been organised. These strategies have not had the expected outcome. Other strategies such as the use of reminders and feedback or a combination of different strategies may be more effective. ${ }^{38}$ First, it is important to identify barriers for adequate prevention, such as knowledge, attitude or clearly defined responsibilities, priority, availability of equipment, costs. ${ }^{37-39}$ To increase their effectiveness, implementation strategies should address these barriers. ${ }^{40}$ The use of tailored multifaceted implementation strategies is another possible option. These strategies may probably improve PU care and patient outcomes since they have been shown to have potential. $^{4142}$

\section{Limitations}

The present study was the largest study inventorying the PU prevalence and preventive interventions in Belgian hospitals based on direct patient observations. Almost $70 \%$ of all Belgian hospitals participated and approximately half of the eligible wards participated including almost 20000 patients. This may possibly have an influence on the representativeness of the sample.

The data on the use of PU prevention materials were based on the observations and reports of the nurses. The repositioning frequency was based on the report in the patient chart and provides only an impression on its reporting. It is possible that these data are overestimations of the actually executed prevention and that the real figures are somewhat lower.

The algorithm to define adequate preventive measures was based on the Belgian evidence-based PU prevention guideline. However, we need to take into account that there is still a lack of evidence about the effectiveness of PU preventive measures. ${ }^{43}$

\section{CONCLUSION}

The overall prevalence of PUs Category I-IV was $12.1 \%$ in Belgian hospitals. Only $10 \%$ of the patients received adequate PU prevention. This study indicates that it is possible to improve the quality of preventive care. Consequently, the incidence of PUs might decrease. The biggest improvement can be gained in the prevention while sitting and the prevention specific for heels. An interesting challenge for the hospitals is to effectively disseminate and implement PU prevention guidelines to individual wards and to address barriers. This may probably improve the quality of PU care and patient outcomes.

Acknowledgements This study was supported by a grant from the Belgian Federal Public Service, Health, Food Chain Safety, and Environment.

Competing interests None.
Ethics approval This study was conducted with the approval of the Ghent University Hospital.

Provenance and peer review Not commissioned; externally peer reviewed.

\section{REFERENCES}

1. Bennett G, Dealey C, Posnett J. The cost of pressure ulcers in the UK. Age Ageing 2004;33:230-5.

2. Health Council of the Netherlands. Pressure ulcers. The Hague: Health Council of the Netherlands, 1999. Report No. 1999/23.

3. Hopkins A, Dealey C, Bale S, et al. Patient stories of living with a pressure ulcer. J Adv Nurs 2006;56:345-53.

4. Nixon J, Nelson EA, Cranny G, et al. Pressure relieving support surfaces: a randomised evaluation. Health Technol Assess 2006;10:iii-x, 1.

5. Edwards $\mathrm{M}$. The rationale for the use of risk calculators in pressure sore prevention, and the evidence of the reliability and validity of published scales. J Adv Nurs 1994;20:288-96.

6. Maklebust J. Pressure ulcer assessment. Clin Geriatr Med 1997;13:455-81.

7. Halfens RJG, Meijers JMM, Neyens JCL, et al. Rapportage resultaten: Landelijke Prevalentiemeting Zorgproblemen 2009 [National Pressure Ulcer Prevalence Survey Health Care Problems 2005]. Maastricht: University Maastricht, 2009.

8. Kottner J, Wilborn D, Dassen T, et al. The trend of pressure ulcer prevalence rates in German hospitals: results of seven crosssectional studies. J Tissue Viability 2009;18:36-46.

9. Vanderwee K, Clark M, Dealey C, et al. Pressure ulcer prevalence in Europe: a pilot study. J Eval Clin Pract 2007;13:227-32.

10. VanGilder C, MacFarlane GD, Meyer S. Results of nine international pressure ulcer prevalence surveys: 1989 to 2005. Ostomy Wound Manage 2008;54:40-54.

11. Whittington K, Briones R. National prevalence and incidence study: 6-year sequential acute care data. Advances in Skin \& Wound Care 2004;17:490-4.

12. Woodbury M, Houghton P. Prevalence of pressure ulcers in Canadian healthcare settings. Ostomy Wound Manage 2004;50:22-38.

13. Barrois $B$, Labalette $C$, Rousseau $P$, et al. A national prevalence study of pressure ulcers in French hospital inpatients. J Wound Care 2008;17:373-9.

14. Agency for Health Research and Quality (AHRQ). Quality indicators - guide to patient safety indicators. Decubitus ulcer (PSI 3). Rockville, MD: AHRQ, 2009. Report No.: Publication No. 03-R203.

15. Allman RM. Pressure ulcers: using what we know to improve quality of care. J Am Geriatr Soc 2001;49:996-7.

16. Defloor T, Herremans A, Grypdonck M, et al. Belgische richtlijnen decubituspreventie 2005 [Belgian guideline pressure ulcer prevention 2005]. Gent: Academia Press, 2005.

17. European Pressure Ulcer Advisory Panel and National Pressure Ulcer Advisory Panel. Prevention and treatment of pressure ulcers: clinical practice guideline. Washington DC: National Pressure Ulcer Advisory Panel, 2009.

18. Bours G, Halfens R, Abu-Saad H, et al. Prevalence, prevention and treatment of pressure ulcers: descriptive study in 89 institutions in the Netherlands. Res Nurs Health 2002;25:99-110.

19. Braden BJ, Bergstrom N. Predictive validity of the Braden Scale for pressure sore risk in a nursing home population. Res Nurs Health 1994;17:459-70.

20. Nixon J, Mc Gough A. Principles of patient assessment: screening for pressure ulcers potential risk. In: Morison $\mathrm{M}$, ed. The prevention and treatment of pressure ulcers. 1st edn. Edinburgh: Mosby, 2001:55-74.

21. Schoonhoven L, Haalboom JRE, Bousema MT, et al. Prospective cohort study of routine use of risk assessment scales for prediction of pressure ulcers. BMJ 2002;325:797-800.

22. Defloor T, Schoonhoven L. Inter-rater reliability of the EPUAP pressure ulcer classification system. J Clin Nurs 2004;13:952-9.

23. Defloor T, Schoonhoven L, Fletcher J, et al. Statement of the European Pressure Ulcer Advisory Panel-pressure ulcer classification: differentiation between pressure ulcers and moisture lesions. J Wound Ostomy Continence Nurs 2005;32:302-6.

24. Boyle M, Green M. Pressure sores in intensive care: defining their incidence and associated factors and assessing the utility of two pressure sore risk assessment tools. Aust Crit Care 2001;14:24-30.

25. Schoonhoven L, Grobbee DE, Donders AR, et al. Prediction of pressure ulcer development in hospitalized patients: a tool for risk assessment. Qual Saf Health Care 2006:65-70.

26. Theaker C, Mannan M, Ives N, et al. Risk factors for pressure sores in the critically ill. Anaesthesia 2000;55:221-4. 


\section{ORIGINAL RESEARCH}

27. Bergstrom N, Braden B. A prospective study of pressure sore risk among institutionalized elderly. J Am Geriatr Soc 1992;40:747-58.

28. Bergstrom N, Braden B, Kemp M, et al. Multi-site study of incidence of pressure ulcers and the relationship between risk level, demographic characteristics, diagnoses, and prescription of preventive interventions. J Am Geriatr Soc 1996;44:22-30.

29. Berlowitz DR, Wilking SV. Risk factors for pressure sores. A comparison of cross-sectional and cohort-derived data. J Am Geriatr Soc 1989;37:1043-50.

30. Nixon J, Cranny G, Bond S. Skin alterations of intact skin and risk factors associated with pressure ulcer development in surgical patients: a cohort study. Int J Nurs Stud 2007;44:655-63.

31. Xakellis GC, Frantz R, Lewis A. Cost of pressure ulcer prevention in long-term care. Journal Am Geriatr Soc 1995;43:496-501.

32. Dealey C. The care of wounds: a guide for nurses. 3rd edn. Oxford: Blackwell Publishing Ltd, 2005.

33. Gunningberg L. Are patients with or at risk of pressure ulcers allocated appropriate prevention measures? Int J Nurs Pract 2005;11:58-67.

34. Lyder $\mathrm{CH}$, Preston J, Grady JN, et al. Quality of care for hospitalized Medicare patients at risk for pressure ulcers. Arch Intern Med 2001;161:1549-54.

35. Baumgarten M, Margolis D, Orwig D, et al. Use of pressureredistributing support surfaces among elderly hip fracture patients across the continuum of care: adherence to pressure ulcer prevention guidelines. Gerontologist 2010;50:253-62.
36. Van Herck P, Sermeus W, Jylha V, et al. Using hospital administrative data to evaluate the knowledge-to-action gap in pressure ulcer preventive care. J Eval Clin Pract 2009;15:375-82.

37. Davies B, Edwards N, Ploeg J, et al. Insights about the process and impact of implementing nursing guidelines on delivery of care in hospitals and community settings. BMC Health Serv Res 2008;8:29.

38. Grol R, Wensing M. Implementatie. Effectieve verbetering van de patiëntenzorg [Implementation. Effective improvement of patient care]. Maarssen: Elsevier Gezondheidszorg, 2006.

39. Clarke HF, Bradley C, Whytock S, et al. van der WR, Gundry S. Pressure ulcers: implementation of evidence-based nursing practice. $J$ Adv Nurs 2005;49:578-90.

40. Grimshaw JM, Thomas RE, MacLennan G, et al. Effectiveness and efficiency of guideline dissemination and implementation strategies. Health Technol Assess 2004;8:iii-72.

41. Shaw B, Cheater F, Baker R, et al. Tailored interventions to overcome identified barriers to change: effects on professional practice and health care outcomes. Cochrane Database Syst Rev 2005;(3): CD005470.

42. van Os-Medendorp $\mathrm{H}$, Eland-de KP, van LR, et al. The tailored implementation of the nursing programme 'Coping with Itch'. J Clin Nurs 2008:17:1460-70.

43. Mclnnes E, Bell-Syer SE, Dumville JC, et al. Support surfaces for pressure ulcer prevention. Cochrane Database Syst Rev 2008;8(4): CD001735. 


\title{
Assessing the adequacy of pressure ulcer prevention in hospitals: a nationwide prevalence survey
}

\author{
Katrien Vanderwee, Tom Defloor, Dimitri Beeckman, et al.
}

BMJ Qual Saf published online January 5, 2011

doi: $10.1136 /$ bmjqs.2010.043125

Updated information and services can be found at:

http://qualitysafety.bmj.com/content/early/2011/01/05/bmjqs.2010.043125.full.html

These include:

References This article cites 31 articles, 4 of which can be accessed free at: http://qualitysafety.bmj.com/content/early/2011/01/05/bmjqs.2010.043125.full.html\#ref-list-1

$\mathbf{P}<\mathbf{P} \quad$ Published online January 5, 2011 in advance of the print journal.

Email alerting

Receive free email alerts when new articles cite this article. Sign up in service the box at the top right corner of the online article.

Notes

Advance online articles have been peer reviewed and accepted for publication but have not yet appeared in the paper journal (edited, typeset versions may be posted when available prior to final publication). Advance online articles are citable and establish publication priority; they are indexed by PubMed from initial publication. Citations to Advance online articles must include the digital object identifier (DOIs) and date of initial publication.

To request permissions go to:

http://group.bmj.com/group/rights-licensing/permissions

To order reprints go to:

http://journals.bmj.com/cgi/reprintform

To subscribe to BMJ go to:

http://group.bmj.com/subscribe/ 